ISSN: 2354 - 1431

http://tckh.daihoctantrao.edu.vn/

\title{
Đông Kinh nghĩa thục - 110 năm nguồn sáng Canh Tân (1907-2017)
}

\section{Phong L $\hat{e}^{a, *}$}

a Viện Hàn lâm Khoa học Xã hội Việt Nam

*Email:kieuhocvietnam@gmail.com

\section{Article info}

Recieved:

12/72017

Accepted:

03/8/2017

\section{Keywords:}

Civilization and democracy; Independence and renovation; National liberalization.

\begin{abstract}
There was a turning point in the first decade of 20 century regarding the national liberalization by Duy Tan movement, Dong Du and Dong Kinh nghia thuc of Buddhists who have patriotism with innovative ideas, aims to two points: civilization and democracy. This was attached with wellknown names such á Phan Boi Chau, Phan Chu Chinh, Luong van Can
\end{abstract}

Dong Kinh nghia thuc only existed from March to December 1097, but its significant operation had created remarkable changes in educational contents and purposes; from education to reform culture; and then to the need of national liberalization from the domination of the colonial.
Năm nay, năm 2017 là chẵn 110 năm khai mở và kết thúc trường Đông Kinh nghĩa thục ${ }^{*}$

Đó là trường tư thục (dân lập) đầu tiên, đem lại một chuyển đổi cách mạng về nội dung và phương thức hoạt động trong lịch sử giáo dục Việt Nam.

Trước đó hàng ngàn năm, nền giáo dục và khoa cử ở ta là một khuôn hình ổn định, nhằm đào tạo các thế hệ kẻ Sỹ, để làm quan hoặc làm thầy. Từ khi chủ nghĩa thực dân Pháp thiết lập được nền thống trị, vào những năm cuối thế kỷ XIX, thì một nền giáo dục Pháp Việt cũng chỉ mới bước đầu hình thành nhằm phục vụ cho mục tiêu "khai hoá" của ông chủ lớn là nước Mẹ.

Còn Đông Kinh nghĩa thục phỏng theo mô hình Khánh Ứng nghĩa thục (Keio Giguku) của Phúc-trạch-dụcát (Fukuzawa Yukichi) khai giảng năm 1858 ở Nhật Bản, là nhằm đưa tư tưởng dân chủ và văn minh khoa học Thái Tây thay cho kinh điển Nho gia để chuyển đổi đầu óc quốc dân, chấn hưng công nghệ, và canh tân đất nước. Thay cho cái học cử tử "chi hồ, dã dã" sẽ là lịch sử, địa dư, cách trí, toán pháp... Là những lý thuyết mới đến từ các trào lưu triết học và tư tưởng dân chủ của phương Tây, qua những cái tên lạ mà hấp dẫn, lần đầu tiên đến với giới trí thức Nho học Việt Nam, như A-lý-sĩ-đa-đức (Aristote), Tư-cách-lạp-đề (Socrate), Bá-lạp-đồ (Platon), Bồi-căn (Bacon), Đích-tạp-nhi (Descartes)... Rồi Lư-thoa (Rousseau), Mạnh-đức-tư-cưu (Montesquieu), Phúc-lộc- đặc-nhĩ (Voltaire)... Là Văn minh tân học sách, với 6 phương án: dùng văn tự nước nhà, hiệu đính sách vở, sửa đổi phép thi, cổ vũ nhân tài, chấn hưng công nghệ, mở toà báo... để dạy cho quốc dân cách thức tự cường, vươn lên, bình đẳng với thiên hạ. Là cả một hệ sách giáo khoa nhằm vào lịch sử dân tộc gồm những Quốc dân độc bản, Quốc văn giáo khoa thur, Nam quốc giai sự, Nam quốc vĩ nhân truyện, Nam quốc sủ luợc, Nam quốc địa dux... bên cạnh Âm băng thất của Lương Khải Siêu, Trung Quốc hồn, Doanh hoàn chí luợc... Là sự tiếp nhận và phổ cập cả một phong trào thơ văn yêu nước từng sôi nổi suốt nửa thế kỷ trước và bây giờ được tiếp tục trên tinh thần mới, như Kêu hồn nuớc, Phen này cắt tóc đi tu (Nguyễn Quyền), Đề tỉnh quốc dân hồn, Hải ngoại huyết thu (Phan Bội Châu), Tỉnh quốc hồn ca (Phan Châu Trinh), Thiết tiền ca (Nguyễn Phan Lãng), Bài ca địa du và lịch sủ nuớc nhà (Ngô Quý Siêu), Á-tế-á ca, Kể chuyện năm châu... Là Cáo hủ lậu văn để phê phán và phủ định cái học hủ lậu hàng nghìn năm và kêu gọi hướng tới một nền học mới... Đây là một cơ hội hiếm có, để cho tất cả những tri thức mới cùng thơ văn yêu nước đến được trực tiếp với công chúng là người đọc, người học, người giảng, người nghe, trong bối cảnh một cuộc duy tân tiếp nhận được từ Nhật Bản và Trung Hoa, vừa phát động đã trở nên sôi động, nhờ vào phương thức hoạt động có tổ chức tương đối bài bản: không chỉ là giảng dạy mà còn là tuyên truyền, cổ động; không chỉ là lý thuyết sách vở mà gắn với thực

\footnotetext{
* Khai giảng tháng 3-1907; đóng cửa tháng 12-1907
} 
nghiệp; không chỉ là thuyết trình mà còn là biên soạn và nhân rộng, "phát tán" các tài liệu... Và cái mới khi đã được công chúng đón nhận trong tâm lý hồ hởi thì sẽ có sức lan toả rất nhanh; chỉ riêng một chuyện kêu gọi cắt tóc mà thành phong trào lan khắp các đô thị Bắc và Trung - phong trào cắt tóc (mouvement de la tonsure) đến từ thơ văn và tràn vào thơ văn: "Cúp hè! Cúp hè! Thẳng thẳng cho khéo. Bỏ cái hèn này. Bỏ cái dại này. Cho khôn cho mạnh. Ở với ông Tây!”; nói rằng: “Ở với ông Tây”, nhưng rồi sẽ bị chính ông chủ Tây truy đuổi và cấm đoán.

Từ địa chỉ số 4 Hàng Đào (nhà riêng của Thục trưởng Lương Văn Can), Đông Kinh nghĩa thục nhanh chóng mở rộng địa bàn hoạt động, không chỉ ở thủ đô 36 phố phường mà còn loang ra nhiều tỉnh thành khác như Sơn Tây, Hà Đông, Thái Bình, Hải Dương, Thanh Hoá, Nghệ An, Hà Tĩnh, Quảng Nam, Quảng Ngãi, Bình Thuận... Chỉ khoảng một năm hoạt động, trong đó có ba tháng chưa có giấy phép, Đông Kinh nghĩa thục đã gây nên một chấn động lớn, chưa từng có trong đời sống văn hoá - tinh thần của dân tộc.

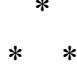

Với Đông Kinh nghĩa thục - đó là một cuộc tập hợp lực lượng trí thức rộng rãi và đông đảo nhất trong lịch sử, nhằm vào mục tiêu canh tân đất nước, bởi cái ý thức sâu sắc có canh tân thì mới cứu được nước. Do mục tiêu đó nên những người chủ trì và cộng tác của Đông Kinh nghĩa thục, tất cả đều là những nhà Nho có đầu óc canh tân trong cả hai phái bạo động và cải cách, “ám xã” và "minh xã", gồm từ Phan Bội Châu, Phan Châu Trinh, Nguyễn Thượng Hiền, Ngô Đức Kế, Đặng Nguyên Cẩn, Trần Quý Cáp... đến Dương Bá Trạc, Hoàng Tăng Bí, Đào Nguyên Phổ, Nguyễn Quyền, Lương Văn Can...; cùng một số trí thức Tây học có vốn Nho học, đang mong muốn tạo một gương mặt mới cho văn hoá, văn chương, học thuật dân tộc như Nguyễn Văn Vĩnh, Nguyễn Bá Học, Phạm Duy Tốn...

Chuyển giao từ nền học cũ sang nền học mới, Đông Kinh nghĩa thục chủ trương dạy cả ba loại chữ: Pháp, Hán, Quốc ngữ; trong đó Pháp đương nhiên là được lòng chính quyền, nhưng sự thật cũng là rất cần để cho giới trí thức trực tiếp đến với nền văn minh chính quốc sau con đường gián tiếp qua Tân thư; Hán - thì mặc dù đã có người quyết liệt phản đối như Phan Châu Trinh: "Bất phế Hán tự bất túc dĩ cứu Nam quốc" (Không bỏ chũ̃ Hán không cứu được nước), nhưng vẫn cần học để không cắt đứt với văn hoá truyền thống; còn $Q u o ̂ ́ c ~ n g \tilde{u}$ thì đương nhiên ở vị trí ưu tiên: "Chữ Quốc ngữ là hồn của nước"... "Chữ ta ta phải thuộc làu...”. Ba loại chữ cho cả ba bậc học: tiểu, trung và đại học; và cho cả hai hệ học sinh nam và nữ - một hiện tượng cực kỳ mới mẻ, chưa từng có trong lịch sử.

Gọi là trường Đông Kinh nghĩa thục, nhưng thực chất là một phong trào - phong trào Đông Kinh nghĩa thục, bởi quy mô hoạt động của nó là gồm đến bốn Ban: Ban Giáo dục, Ban Tài chính, Ban Cổ động, Ban Tu thư nhằm chăm lo cho sự tồn tại và mở rộng hoạt động của Đông Kinh nghĩa thục, để từ khởi động là giáo dục với mục tiêu cải tạo và nâng cao dân trí mà chuyển sang văn hoá với mục tiêu là chấn hưng và canh tân đất nước, để đi đến cái đích cuối cùng là giải phóng dân tộc.

Ta hiểu vì sao trong các tài liệu giáo khoa và thơ văn yêu nước được dùng để giảng dạy ở Đông Kinh nghĩa thục lại xuất hiện nhiều và dồn dập đến thế những Nam quốc, quốc dân, quốc hồn và hồn nuớc, với một thiết tha "đề tỉnh".

Và câu thơ đúc kết được đầy đủ nhất tinh thần Đông Kinh nghĩa thục, đó là:

\section{Tụng kinh Độc lập ở chùa Duy tân}

Một thức nhận với những mục tiêu và biện pháp tổ chức như thế vào thập niên mở đầu thế kỷ $\mathrm{XX}$, khi đất nước còn trong tối tăm mù mịt sau thất bại của biết bao tên tuổi sỹ phu - văn thân trong suốt nửa thế kỷ trước đó, phải nói là cực kỳ mới mẻ.

Bị bủa vây và rình rập của chính quyền thuộc địa, sự tồn tại của một trường tư thục phải tìm đến sự tập hợp rất lớn của đội ngũ trí thức, và sự hưởng ứng của quốc dân đang khao khát một cuộc đổi mới (canh tân), để khua dậy một cơn mê ngủ kéo quá dài trong lịch sử; bởi, theo họ, chính vì cơn mê ngủ đó mà đưa tới thảm hoạ mất nước:

Sao không đập mạnh thét dài

Cho người mê ngủ ai ai tỉnh dần?

Sao không chống mảng mê tân

Cho nguời chìm đuối lần lần vượt lên?

\section{(Cáo hủ lậu văn)}

Tất nhiên đến được đích ấy, con đường còn rất xa; nhưng ít nhất phải có được một tỉnh thức, như một khởi động.

Và tất nhiên, chỉ một khởi động như thế, với gương mặt ngỡ như rất ôn hoà, chỉ nhằm cải tạo và nâng cao dân trí, chấn hưng dân khí, thế mà thực dân đã rất kinh sợ. Bởi, với giác quan nhậy bén của kẻ đi xâm lược, bọn chúng đã "ngửi” thấy một cái gì thật bất an đang nhen nhóm ở phía dưới. Trong gắn nối với phong trào Duy tân và Đông du hai năm về trước, và trong sự bùng nổ về sau, vào năm 1908, phong trào chống thuế 
ở Quảng Nam, cuộc bạo động của Đề Thám và vụ đầu độc Hà Thành, Đông Kinh nghĩa thục sẽ bị đóng cửa sau 9 tháng hoạt động. Và ít lâu sau ngày đóng cửa, gần như tất cả những ai có liên quan và đóng góp cho Đông Kinh nghĩa thục đều bị bắt, rồi bị giam cầm, đầy ra Côn Đảo, với những cái án giam hàng chục năm, có người là chung thân, hoặc "trảm giam hậu” (tội chém nhưng chưa phải chém ngay); trong đó Lê Đại chịu án 15 năm, nhiều người khác chịu án chung thân; riêng Phan Châu Trinh bị "trảm quyết" sau đổi thành "trảm giam hậu"...

Có thể nói sau cuộc tàn sát năm Thân (1908), năm Dậu (1909) diễn ra ngay sau ngày Đông Kinh nghĩa thục vỡ, cả một thế hệ trí thức Nho học yêu nước có đầu óc canh tân đã bị giam cầm, đầy ải. Hết đất hoạt động, trong thân phận bị tù đày hoặc giam lỏng, họ chỉ có thể ngụ tâm sự và ý chí của mình vào những vần thơ cảm khái, làm nên một dòng thơ tù đặc sắc, khởi phát từ Côn Lôn của Phan Châu Trinh, Huỳnh Thúc Kháng, Đặng Nguyên Cẩn... tiếp tục dòng thơ yêu nước ở ngoài đời. Có người trở lại việc ôn luyện Quốc ngữ hoặc học tiếng Pháp chỉ bằng một cuốn Từ điển, nhằm chuẩn bị hành trang cho ngày vượt tù hoặc ra tù. Cho đến hết Thế chiến lần thứ nhất, các án giam lần lượt được giảm, để vào mở đầu thập niên 1920, họ lần lượt được trả tự do. Báo chí trở thành môi trường quan trọng cho sự tiếp tục chí hướng cách mạng của họ, như Ngô Đức Kế, Huỳnh Thúc Kháng, Phan Khôi... Nhưng thời thế đã thay đổi kể từ sau Cách mạng tháng Mười Nga 1917. Sứ mệnh lịch sử giải phóng dân tộc đã chuyển sang vai một thế hệ mới, thế hệ con em của họ, mà Nguyễn Ái Quốc là tên tuổi số 1 , đã chọn con đường sang phương Tây, và bắt đầu sự nghiệp viết của mình ở tuổi 30 ở Paris, như một động thái chuẩn bị tích cực cho cuộc hành trình mới của dân tộc, với những áng văn đầu tiên khai mạc một thời đại mới - đó là Yêu sách của nhân dân Việt Nam - năm
1919, là Đông Dương thức tỉnh - năm 1921, và Bản án chế độ thực dân Pháp - năm 1925.

Nhưng dẫu có bị ngắt quãng, bị đứt đoạn thì tinh thần canh tân đất nước của Đông Kinh nghĩa thục vẫn có được sự nối tiếp qua các thế hệ; bởi cốt lõi tư tưởng: yêu nước gắn với canh tân (có nghĩa là có đổi mới đất nước mới giành và giữ được đất nước) Đông Kinh nghĩa thục mở ra là có giá trị cho cả một thế kỷ - để đến với sự nghiệp Đổi mới do Đảng Cộng sản Việt Nam lãnh đạo từ thập niên cuối thế kỷ XX. Bên cạnh truyền thống yêu nước và bất khuất của dân tộc có lịch sử nhiều nghìn năm thì khát vọng canh tân chỉ có thể có hoàn cảnh phát triển để trở thành phong trào chỉ trong khoảng hơn 100 năm, với khởi đầu rực rỡ và chói sáng Đông Kinh nghĩa thục và những gương mặt lớn như Phan Bội Châu, Phan Châu Trinh, Nguyễn Thượng Hiền, Trần Quý Cáp, Lương Văn Can, Nguyễn Quyền...

Lịch sử sẽ đi tiếp hành trình của Đông Kinh nghĩa thục, trong những sự kiện vang động cả nước vào những năm 1920 ngay sau khi kết thúc Thế chiến lần thứ nhất, với tiếng bom nổ ở Sa Điện (Quảng Châu) của Phạm Hồng Thái nhằm mưu sát Toàn quyền Đông Dương Meclanh năm 1924, phong trào đòi thả Phan Bội Châu năm 1925, phong trào đòi để tang Phan Châu Trinh năm 1926, và đám tang Lương Văn Can năm 1927, cũng là năm Nguyễn Ái Quốc công bố tác phẩm Đường Kách mệnh tại Quảng Châu, chuẩn bị cho sự ra đời của Đảng Cộng sản Đông Dương năm 1930. Con đường mở ra cho dân tộc sau các phong trào Đông Du, Duy Tân và Đông Kinh nghĩa thục, do một thế hệ các nhà Nho chí sĩ mở đường, sẽ vươn tới một tầm cao, một mục tiêu mới, đòi hỏi một nỗ lực lớn, hướng theo sự chỉ dẫn của một Đảng của giai cấp công nhân với lãnh tụ tối cao là Nguyễn Ái Quốc, để đón bắt kịp thời thời cơ cách mạng rồi sẽ đến với dân tộc vào thời điểm tháng Tám - 1945 lịch sử. 